\title{
THE TRANS LEVEL CHARACTERISTICS ABOUT INFINITE SERIES
}

\author{
Wahyu Widada ${ }^{1}$, Dewi Herawaty ${ }^{2}$, Abdurrobbil Falaq D Anggoro ${ }^{3}$, Khathibul \\ Umam Z Nugroho ${ }^{4}$ \\ ${ }^{1,2,3,4}$ Prodi Pendidikan Matematika Fakultas Keguruan dan Ilmu Pendidikn, Universitas Bengkulu \\ Jalan WR Supratman, Kandang Limun, Muara Bangka Hulu, Bengkulu, Indonesia \\ e-mail: ${ }^{1}$ w.widada@unib.ac.id; ${ }^{2}$ dherawaty@unib.ac.id; ${ }^{3}$ robbifda2299@gmail.com; \\ ${ }^{4}$ nugrohoumam@gmail.com;
}

\begin{abstract}
Abstrak
Deret tak hingga adalah salah satu materi kalkulus yang sulit bagi mahasiswa. Ini perlu dianalisis aktivitas kognitif siswa untuk menyiapkan perencanaan pembelajaran. Tujuan penelitian ini adalah untuk mendeskripsikan karakteristik level trans tentang seri infinite. Subjek penelitian ini adalah siswa Pendidikan Matematika, salah satu universitas di Bengkulu. Sebanyak 5 orang dipilih dari 29 siswa berdasarkan kemampuan kognitif mereka. Subjek diwawancarai berdasarkan tugas yang diberikan. Data dinalisis melalui dekomposisi genetiknya. Hasil penelitian adalah subjek dapat mengoordinasikan objek dan proses lain, sehingga skema matang terbentuk tentang konvergensi barisan dan deret tak hingga. Simpulannya: subjek mampu melakukan tematisasi sehingga menghasilkan karakteristik yang lebih sesuai dengan level trans
\end{abstract}

Kata Kunci: apos, karakteristik, level trans

\section{THE TRANS LEVEL CHARACTERISTICS ABOUT INFINITE SERIES}

\begin{abstract}
Infinite series is one of the difficult calculus material for students. It needs to be analyzed the cognitive activities of students to make it easier for lecturers to arrange learning plans. The purpose of this study is to describe the characteristics of the trans level about infinite series. The subject of this research was a student of Mathematics Education, one of the universities in Bengkulu. A total of 5 people were selected from 29 students based on their cognitive abilities. Subjects were interviewed based on the assignment given. Data is analyzed through its genetic decomposition. The results of the study are that subjects can coordinate other objects and processes, so that the scheme is formed about the convergence of infinite series and sequences. Conclusion: the subject is able to do thematization so that forming a mature scheme is a trance level characteristic.
\end{abstract}

Keywords: apos, trans level, characteristics

\section{Intoduction}

Real analysis is one difficult subject. Its structuralitic characteristics make students many obstacles (Widada, 2016) (Suharto \& Widada, $2019 \mathrm{~b})$. It is primarily the ability to prove and compile his arguments (Widada et al., 2019) (Jr \& Vidakovic, 2015). One of them is proving convergence of infinite series or sequence.

Therefore, this needs to be addressed through meaningful learning (D. Herawaty,
Widada, Novita, Waroka, \& Lubis, 2018) (Brijlall \& Bansilal, 2011). Students must be trained to make arguments in solving problems (Tziritas, 2011). To make a meaningful learning plan, the lecturer must know the students' initial abilities. It is stored in long-term memory. The mathematical learning that is meaningful makes it easy for students to develop mature schemes in the student's body of knowledge (Widada et al., 2019). We must dig it through task-based interviews. This is one technique in needs 
analysis. The lecturer ensures students have sufficient initial knowledge to study further.

Students are active information processors. Students are able to represent each information according to the level of knowledge they have (Widada, 2006). Cognitive development is not an accumulation of separate information, but rather is the construction of a mental framework by students to understand their environment. Free students build their own understanding (Widada, 2002).

Abstraction is the main focus in extensive educational problems, including mathematics education (Widada, Sunardi, Herawaty, Pd, \& Syefriani, 2018) (Dewi Herawaty \& Rusdi, 2016). In this case the process aspect takes precedence over the outcome. (Tsamir \& Dreyfus, 2002) states that the process of abstraction is a process where students are given the freedom to reorganize mathematics vertically in a mathematical structure. Abstraction requires a thought process and its own ability to present knowledge to obtain new structures. It is the main activity that can be carried out by individuals in obtaining a picture of a conclusion logically from the information presented (Widada, 2016).

Efforts to understand students' abilities have been carried out by several previous studies through task-based interviews. One of them is task-based interviews about convergence of infinite series (Widada, 2006). Cognitive structure capable of adapting a new stimulus will give its own meaning to individuals in learning. An individual is free in developing his thought patterns in realizing his learning experience (Widada \& Herawaty, 2017).

Intellectual development is very influential on mental activities carried out by individuals in specifying a problem through cognitive levels, both the level of empirical thinking and the level of theoretical thinking possessed (Suharto \& Widada, 2019a)(Suharto \& Widada, 2019b). Personal ability to associate existing knowledge structures with other components associated with these structures greatly influences the process of abstraction carried out (Widada et al., 2019).

Students understand mathematical objects through a process to achieve a concept. According to Gray \& Tall (2007), the shift from arithmetic to algebra involves abstraction from arithmetic counting operations to the use of expressions that represent general arithmetic operations. Such transitions prove to be relatively easy for some who have a flexible, arithmetic approach, but it is far more difficult for those who continue to think of pure expressions in procedural terms. This requires interconnection between schemes (Widada et al., 2019). There are five levels in the interaction of the new model scheme. The five levels are sequentially ordered, intra level as level 0 , semiinter level as level 1, inter level as level 2, semitrans level as level 3, and trans level as level 4 (Widada \& Herawaty, 2017).

To analyze students' thinking activities in understanding mathematics can be done through genetic decomposition (Widada, 2006) (Widada \& Herawaty, 2017)(Widada et al., 2019). It is the operationalization of the APOS Theory (Dubinsky, 2010). APOS theory is a constructivist theory about how the possibility of achievement / learning of a mathematical concept or principle, which can be used as an elaboration of mental constructs of actions, processes, objects, and schemes (Dubinsky \& Mcdonald, 2001)(Dubinsky， 2010)(Zazkis \& Campbell, 1996).

Thinking activity is a pattern of interrelated ideas that appear to be clearly related in one's thinking (Widada, 2016). The pattern of ideas can be seen through the mental construction of a person who is made to achieve and understand mathematical concepts and principles. An understanding of mathematical concepts is the result of the construction or reconstruction of mathematical objects. Construction or reconstruction is carried out through activities in the form of mathematical actions, processes, objects organized in a scheme to solve a problem (Widada et al., 2019) (Herawaty \& Widada, 2018).

Thus, we focus on discussing how cognitive processes of students are at the trans level. Students are triggered through task-based interviews about the convergence of infinite series.

\section{Methods}

The subject of this research was students of Mathematics Education, one of the universities in Bengkulu. A total of 5 people were selected from 29 students based on their cognitive abilities. This research was conducted in a participatory manner in the regular learning process. Subjects were interviewed based on the assignment given. students are asked to solve the problem:

\footnotetext{
Sequences (uk) are known, with $u k=\cos (\pi / k)$.

a. Investigate, is (uk) convergent? If yes, specify $\lim _{k \rightarrow \infty} \cos (\pi / k)$.
} 
b. Then determine, is it $\sum_{\mathrm{k}=1}^{\infty} \mathrm{u}_{\mathrm{k}}$ convergent? Show the truth of your conclusions!

(Hint: to complete part $b$, if necessary you can use completion of part a)

The subject was explored about cognitive processes in solving the problem of convergence of infinite series. The main instrument is the researcher himself. Data were analyzed qualitatively by applying genetic decomposition. To get the characteristics of the trans level, the description of genetic decomposition is continued by the fixed comparison method (Glaser \& Strauss, 1980).

\section{Result and Discussion}

Data from task-based interviews were analyzed through genetic decomposition of convergence of infinite series. Thinking activities begin with the registration of the initial stimulus, which is followed by a process through the infinite interiorization given. A few minutes students finish paper and pencil. Then he was immediately interviewed based on work in his paper. He was asked to explain the process and results of problem solving. Here are some excerpts of interviews with the subject of KM.

P: You asked me to solve the Problem 2 about the convergence of infinite series. Please complete the problem!

KM2.01: Thank you [... Shut up ...] [KM works with paper and pens to solve problems for 10 minutes.]

P: Okay! You have solved problem 2, please explain!

KM2.02: Know (uk) a sequence with $u k=c o s$ $(\pi / k)$. To investigate convergence (uk), there is a theorem which states that, if $(u k)$ is monotonically up and limited, then (uk) is convergent.

P: Okay! ...

KM2.03: because $k<k+1$ for every natural number $k$, then $\pi / k>\pi /(k+1)$, and ... $\cos (\pi / k)<\cos (\pi /(k+1))$, for every $k \epsilon$ $N$, the meaning of the sequence is monotonically up. [KM designates worksheets like KM2.03]

P: Okay!

KM2.04: Then it can be taken that $0<\pi / k<\pi$, for every $k \in N$, so $\cos 0>\cos \pi / k>\cos \pi$, the value is equal to $1>\cos \pi / k>-1$, which means the sequence it's limited. [KM shows work results as intended by KM2.04]
$P$ : What can you conclude!

KM2.05: ... convergent sequence ( $\cos \pi / k$ ) and limit from $(\cos \pi / k)$ to $k$ to infinity equal to 1. [KM designates worksheet like KM2.05]

P: Why 1?

KM2.06: Because the limit $k$ towards infinity of $\cos (\pi / k)$ is equal to cos from the limit for $k$ to infinity of $(\pi / k)$ equals cos 0 and the result is 1. [KM refers to sheet.

Footage of the interview suggests that KM can coordinate objects in KM2.02, and processes KM2.03-KM2.06, so that a mature scheme of convergence is formed. The results of this scheme are conclusions about the sequence (uk) converging with its limits 1 . As the results of the study by Widada \& Herawaty (2017) the subject builds a link between actions, processes, objects, and other schemes (doing retrieval of the previous schema ) (Baker, Cooley, Trigueros, \& Trigueros, 2000), so that a mature schema is formed. The same results can also be seen (Widada, 2015), (Widada et al., 2019), (Widada \& Herawaty, 2017).

The subject was asked to explain the convergence of infinite series. The results of taskbased interviews are summarized in the following snippet.

P: Okay! ... Now what about part b?

KM2.07: ... for which b) I use the theorem, that if the infinite series $\sum u_{k}$ is convergent, the limit of the row (uk) is equal to 0 . And what I use is counterparts; if the line limit (uk) is not equal to 0 , then the infinite series $\sum u_{k}$ is not convergent. [KM shows the theorem written on the worksheet as meant by KM2.07]

$P$ : Why is that!

KM2.08: Because from part a) it has been found that the limit from $(\cos \pi / k)$ to $k$ to infinity equals 1 which means it is not equal to zero. . [KM designates worksheets like KM2.08]

$Q:$ What are your conclusions?

KM2.09: ... with infinite $\sum u_{k}$ not convergent.

$P$ : What is the next explanation!

KM2.10: For example, the series does not converge to $s$, and also the infinite series $u_{k+1}$ converges to s, whereas $u k=\sum u_{k}-$ $\sum u_{k+1}$, means the limit un to $n$ to infinity is equal to $s-s=0$. [KM designates worksheets like KM2.10]

$P$ : Which one do you show?

KM2.11: ... the theorem used ... which is equivalent to its counterparts. 
Excerpts of this interview make it clear that $\mathrm{KM}$ can coordinate the object and its progress in $\mathrm{KM} 2.07$, and the scheme of converging sequence parts a) (see KM2.08), and the KM2.10 process so that a mature scheme is formed about converging infinite series.

Based on genetic decomposition of convergence of infinite series, the development of convergence schemes and the development of the convergence scheme of series are infinite. For convergence conditions, KM can coordinate objects and processes, so that a mature scheme is formed about the convergence of sequences. From the description above, and according to the characteristics of the triad theory (Cooley, Trigueros, \& Baker, 2007)(Baker et al., 2000)(Zazkis \& Campbell, 1996), for the convergent conditions of the given sequence, KM enters the trans level.

For conditions of infinite series convergence, $\mathrm{KM}$ can coordinate object processes, and schemes about convergence of sequences, so that a mature scheme of converged infinite series is formed. The characteristics of the triad theory (Dubinsky, 2000)(Widada, 2016), for the conditions of the function given, $\mathrm{KM}$ enters the trans level. KM can coordinate objects and processes, so that a mature scheme is formed about the convergence of sequences. The mature scheme of convergence of these sequences is coordinated by KM with other object processes, so that a mature scheme is formed about convergence of infinite series and sequences. KM is students who are at the trans level (Widada, 2015). He can coordinate other objects and processes, so that a mature scheme is formed about the convergence of infinite series and sequences.

\section{Kesimpulan}

Genetic decomposition analysis of the convergence of infinite series shows results that are consistent with previous studies. Therefore we believe that the characteristics of the trans level of infinite series are that students are able to coordinate the action-process-objects and thematic schema. This results in a mature scheme.

Finally, we would like to thank the Chancellor, Dean of FKIP and PMIPA department head at the University of Bengkulu.

\section{Daftar Pustaka}

Baker, B., Cooley, L., Trigueros, M., \& Trigueros, M.
(2000). A Calculus Graphing Schema. Journal for Research in Mathematics Education, 31(5), 557=578. https://doi.org/10.2307/749887

Brijlall, D., \& Bansilal, S. (2011). Student Teachers ' Engagement With Re-Contextualized Materials : A Case of Numerical Approximation. US-China Education Review, 5(June), 691-702.

Cooley, L., Trigueros, M., \& Baker, B. (2007). Schema Thematization: A Framework and an Example. Journal for Research in Mathematics Education, $38(4)$, https://doi.org/10.2307/30034879

Dubinsky, E. (2000). Using a Theory of Learning in College Mathematics Courses. MSOR Connections, $1(2), \quad 10-15$. https://doi.org/10.11120/msor.2001.01020010

Dubinsky, E. (2010). Using a Theory of Learning in College Mathematics Courses. MSOR Connections, $1(2), \quad 10-15$. https://doi.org/10.11120/msor.2001.01020010

Dubinsky, E., \& Mcdonald, M. A. (2001). APOS : a Constructivist Theory of Learning in Undergraduate Mathematics Education. Netherlands: Kluwer Academic Publishers.

Glaser, B. G., \& Strauss, A. . (1980). The Discovery of Grounded Theory. New York: Aldinie de Gruyster Inc. Bogdan.

Gray, E., \& Tall, D. (2007). Abstraction as a Natural Process of Mental C o m p r e s s i o n. Mathematics Education Research Journal, 19(2), 23-40.

Herawaty, D., Widada, W., Novita, T., Waroka, L., \& Lubis, A. N. M. T. (2018). Students' metacognition on mathematical problem solving through ethnomathematics in Rejang Lebong, Indonesia. Journal of Physics: Conference Series, 1088. https://doi.org/10.1088/17426596/1088/1/012089

Herawaty, D, \& Rusdi, R. (2016). Increased Capacity Of The Understanding Of The Concept And The Ability To Solve Problems Through The Implementation Of The Model Of Teaching Mathematics Realistic Based On Cognitive Conflict Students. Journal of Mathematics Education (Infinity), 5(2), 109-120. https://doi.org/10.22460/infinity.v5i2.217

Herawaty, D., \& Widada, W. (2018). The Influence of Contextual Learning Models and the Cognitive Conflict to Understand Mathematical Concepts and Problems Solving Abilities. Advances in Social Science, Education and Humanities Research, 218(ICoMSE 2017), 96-102. https://doi.org/10.2991/icomse-17.2018.17

Jr, D. C., \& Vidakovic, D. (2015). Developing Student Understanding: The Case of Proof by Contradiction.

Suharto, S., \& Widada, W. (2019a). The Cognitive Structure of Students in Understanding Mathematical Concepts. Advances in Social Science, Education and Humanities Research, Volume 295, 295(ICETeP 2018), 65-69.

Suharto, S., \& Widada, W. (2019b). The Contribution of Mathematical Connection and Mathematical 
Communication to Problem Solving Ability. International Journal of Science and Research (IJSR), 8(1), 155-159.

Tsamir, P., \& Dreyfus, T. (2002). Comparing Infinite Sets - a process of abstraction. TheCase of Ben. In The Journal of Mathematical Behavior, 21(1).

Tziritas, M. (2011). APOS Theory as a Framework to Study the Conceptual Stages of Related Rates Problems. Analysis, (September), 213.

Widada, W. (2002). Teori APOS sebagai Suatu Alat Analisis Dekomposisi Genetik terhadap Perkembangan Konsep Matematika Seseorang. Journal of Indonesian Mathematicel Society (MIHMI), 8(3).

Widada, W. (2006). Dekomposisi Genetik Mahasiswa dalam Mempelajari Teori Graph. Jurnal Ilmiah Multi Science Inspirasi, Monograph.

Widada, W. (2015). The Existence of Students in Trans Extended Cognitive Development on Learning of Graph Theory. Jurnal Math Educator Nusantara, 1(1), 1-20.

Widada, W. (2016). Profile Of Cognitive Structure Of Students In Understanding The Concept Of Real Analysis. Journal of Mathematics Education (Infinity), 5(2), 83-98. https://doi.org/10.22460/infinity.v5i2.215

Widada, W., \& Herawaty, D. (2017). Dekomposisi Genetik tentang Hambatan Mahasiswa dalam Menerapkan Sifat-sifat Turunan. Jurnal Didaktik Matematika, 4(2), 136-151. https://doi.org/10.24815/jdm.v4i2.9216

Widada, W., Herawaty, D., Umam, K., Nugroho, Z., Falaq, A., \& Anggoro, D. (2019). The Scheme Characteristics for Students at the Level of Trans in Understanding Mathematics during EtnoMathematics Learning. Advances in Social Science, Education and Humanities Research, 253(Aes 2018), 417-421.

Widada, W., Sunardi, H., Herawaty, D., Pd, B. E., \& Syefriani, D. (2018). Abstract Level Characteristics in SOLO Taxonomy during Ethnomathematics Learning. International Journal of Science and Research (IJSR), 7(8), 352-355. https://doi.org/10.21275/ART2019438

Zazkis, R., \& Campbell, S. (1996). Divisibility and Multiplicative Structure of Natural Numbers: Preservice Teachers' Understanding. Journal for Research in Mathematics Education, 27(5). https://doi.org/10.2307/749847 
